\title{
Organik ve İnorganik Gübre Uygulamalarının Karabuğdayda Kök Gelișimine Etkisi
}

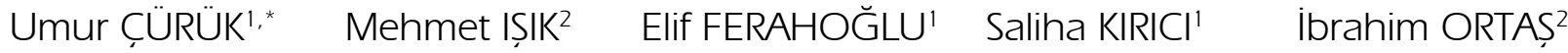 \\ 'Çukurova Üniversitesi, Ziraat Fakültesi, Tarla Bitkileri Bölümü, 01330, Adana \\ ${ }^{2}$ Çukurova Üniversitesi, Ziraat Fakültesi, Toprak Bilimi ve Bitki Besleme Bölümü, 01330, Adana.
}

\begin{abstract}
*Sorumlu yazar e-mail (Corresponding author e-mail): umurcuruk@gmail.com
Geliș tarihi (Received) : 24.02.2020

Kabul tarihi (Accepted): 02.10.2020

DOI: $10.21657 /$ topraksu.693276
\end{abstract}

\section{Öz}

Zengin protein, karbonhidrat, mineral ve vitamin içeriği ile insan beslenmesi açısından son derece sağılıkı olan karabuğday (Fagopyrum esculentum) bitkisi aynı zamanda hastalık olușma riskini azaltan gıdalar (fonksiyonel gıdalar) arasında yer alıp özellikle çölyak hastaları tarafından kullanılmaktadır. Karabuğday bitkisinin gelișimini sağlayabilmesi için gelișmiș bir kök sistemine intiyacı vardır. Literatürde kök morfolojik özelliklerine ilișkin çok az çalıșma olduğu belirlenmiștir. Bu bağlamda çalıșmanın amacı; iki farklı karabuğday çeșidinde, organik ve inorganik gübre uygulamalarının bazı bitki kök parametreleri (uzunluk, alan, hacim ve çap) üzerine etkisini araștırmaktır. Deneme Çukurova Üniversitesi, Ziraat Fakültesi Tarla Bitkileri Bölümü Araștırma ve Uygulama Alanında 2019 yılında, bölünmüș parseller deneme desenine göre kurulmuștur. Denemede tescilli Aktaș ve Güneș karabuğday çeșitleri kullanılmıștır. Çalıșmada 5 gübreleme uygulaması (Kontrol, Üre, Solucan gübresi, Tavuk gübresi, Sığır gübresi) uygulanmıștır. Karabuğday ekimi Nisan 2019'da yapıımıș, Temmuz 2019'da da hasat edilmiștir. Hasat ile birlikte birim m² alanda bitki kökleri örneklenip yıkandıktan sonra laboratuvarda WinRhizo programı yardımı ile bitki kök morfolojik özellikleri belirlenmiștir. Araștırma bulgularına göre, kök uzunluğu bakımından gübre uygulamalarının arasında istatistiksel olarak önemli bir farklılık saptanmıștır. Kök uzunluğu bakımından en iyi uygulama tavuk gübresi $(39.7 \mathrm{~km}$. da' $)$ olurken onu üre $\left(27.8 \mathrm{~km}\right.$. da' $\left.{ }^{-1}\right)$ izlemiștir. Kök alanı ve kök hacmi parametreleri yönünden farklı çeșitler ve farklı gübreler arasında ayrıca istatistiksel önemlilik belirlenmiștir. Aktaș karabuğday çeșidinde Güneș çeșidine göre kök gelișiminin arttığı saptanmıștır. Gübre uygulamalarından ise tavuk gübresi ve üre gübre uygulamaları kontrole göre kök gelișimini daha iyi arttırmıștır.

Anahtar Kelimeler: Karabuğday, kök morfolojik özellikleri, organik gübreler

\section{The Effects of Organic and Inorganic Fertilizer Applications on Buckwheat Root Development}

\section{Abstract}

The buckwheat (Fagopyrum esculentum) is very healthy for human nutrition with its rich protein, carbohydrate, mineral and vitamin content. It is also among the functional foods that reduce the risk of disease especially used by celiac patients. The buckwheat plant needs an advanced root system for its healthy growth. It has been found that there is a very few studies in the literature on root morphological characteristics of buckwheat plant. The aim of study is to investigate the effect of organic and inorganic fertilizer applications on two different buckwheat varieties some plant root parameters (length, area, 
volume and diameter). The experiment was established as randomize design in split-plots in 2019 in Cukurova University, Department of Field Crops Research and Application. Aktaș and Güneș buckwheat varieties were used in the experiment. Five different fertilizers (Control, Urea, Worm-manure, Chickenmanure, Cattle-manure) were used. Buckwheat cultivar were cultivated in April 2019 and harvested in July 2019 . After harvesting, the roots were sampled, washed and the morphological characteristics were determined by WinRhizo program. In terms of root length, statistically a significant difference was found between the fertilizer treatments. In terms of root length, the best practice was chickenmanure $\left(39.7 \mathrm{~km} . \mathrm{da}^{-1}\right)$, followed by mineral urea $(27.8 \mathrm{~km}$. da-1 $)$. Statistically significant differences were determined between different buckwheat varieties and different fertilizers in terms of root area and root volume parameters. Aktaș cultivar increased the root growth better than that of Güneș cultivar. Among the fertilizer applications, chicken-manure and urea fertilizer applications increased root growth better than control treatment.

Keywords: Buckwheat, root morphology, organic fertilizer

\section{Giriș}

Polygonaceae familyasından Fagoppyrum cinsine dahil olan karabuğday bitkisinin bilinen 15 türü bulunmaktadır. Bu türler arasında kültürü yapılan en önemli karabuğday türlerinden birisi Fagopyrum esculentum Moench'dir (Chauhan vd., 2010, Hayit ve Hülya, 2015).

Karabuğday zengin protein, karbonhidrat, mineral ve vitamin içeriği ile insan beslenmesi açısından son derece önemlidir. İnsan beslenmesinde ekmek, makarna, tarhana, kraker, kurabiye gibi ürünlerin üretiminde kullanımı dıșında hayvan beslemede yem olarak, yeșil gübre olarak, toprak düzenleyicisi olarak, sirke, bira, çay, ispirto gibi ürünlerin üretiminde kullanılmaktadır. İçerisinde glüten bulunmaması nedeniyle özellikle çölyak hastaları tarafından tüketilmektedir (Acar vd., 2011).

Bitkinin toprakta iyi bir gelișim göstermesi için sağlıklı ve gelișmiș bir kök sistemine sahip olması gerekir. Bu durumun yetiștiği toprak ortamının fiziksel ve kimyasal özellikleri ile ilișkili olduğu düșünüldüğünde toprağın fiziksel özelliklerini düzeltmede ve sürekliliğini sağlamada toprağa organik kökenli materyallerin ilavesi oldukça önem arz etmektedir. Dolayısıyla toprak iyileștiricisi olarak organik gübreler kullanılabilir (Soyergin, 2003). Giderek artan gübre fiyatları (Anonim, 2019) ile inorganik gübrelerin așırı kullanımının toprağın fiziksel ve kimyasal özelliklerine olumsuz etkilerinin olduğu dikkate alındığında organik kökenli materyallerin uygulanmasının önemi gün geçtikçe daha da artırmaktadır (Alagöz vd., 2006).

Organik gübreler mineral besin elementi, su tutma kapasitesi, strüktür stabilitesi ve KDK gibi pek çok toprak özelliğini iyileștirmenin yanı sıra bitki kök morfolojik özelliklerini de arttırabilmektedir (Chen, 2006). Örneğin Yang vd. (2004) yapmıș olduğu çalıșmada kimyasal gübre uygulamasına göre ahır gübresi ve bitkisel anız artıklarının bazı bitki kök morfolojik özelliklerini arttırdığı görülmektedir.

Kök morfolojisi ve fizyolojisi doğrudan verimi ilgilendirdiğinden için (Su vd., 2019) karabuğday için etkili kök sistemi büyük öneme sahiptir. Örneğin Svačina vd., (2014) arpa bitkisinde yaptıkları çalıșmada etkili kök sisteminin verim ve kaliteyi arttırdığını belirtmișlerdir. Wang vd. (2015) ise mısır bitkisinde yaptıkları çalıșmada benzer șekilde kök gelișiminin verimi arttırdığını tespit etmișlerdir. Kök gelișiminin verimi etkilemesinin yanı sıra kuraklık stresine karșı bitkinin direncini ve bitkinin beslenmesini arttırdığı da bilinmektedir (Su vd., 2019). Bu noktadan hareketle karabuğday verimi ve gelișimi için etkili kök sistemi büyük öneme sahiptir. Literatürde karabuğday kök morfolojisi ile ilgili çalıșmalar kısıtlı olup söz konusu çalıșma ile bu açığın kapatılması hedeflenmektedir. Bu bağlamda çalıșmanın amacı; iki farklı karabuğday çeșidinde, organik ve inorganik gübre uygulamalarının bazı bitki kök parametreleri (uzunluk, alan, hacim ve çap) üzerine etkisini araștırmaktır.

\section{MATERYAL VE YÖNTEM}

Organik ve inorganik gübre uygulamalarının karabuğdayda kök gelișimine etkisinin araștırıldığı bu çalıșmada bitkisel materyal olarak karabuğday bitkisinin tescilli Aktaș ve Güneș çeșitleri kullanılmıștır. Deneme Cukurova Üniversitesi Ziraat Fakültesi Tarla Bitkileri Araștırma ve Uygulama Alanında bölünmüș 
Çizelge 1. Organik gübrelerin kimyasal analiz sonuçları

Table 1. Chemical analysis results of organic fertilizers

\begin{tabular}{|c|c|c|c|c|c|c|c|c|c|c|}
\hline Gübreler & $\mathrm{N}$ & $P$ & $\mathrm{~K}$ & Ca & $\mathrm{Mg}$ & $\mathrm{Fe}$ & $\mathrm{Zn}$ & $\mathrm{Mn}$ & $\mathrm{Cu}$ & $\mathrm{B}$ \\
\hline & & & $(\%)$ & & & \multicolumn{5}{|c|}{$\left(\mathrm{mg} \mathrm{kg}^{-1}\right)$} \\
\hline Sığır G. & 2.4 & 0.66 & 1.16 & 4.11 & 0.63 & 1308 & 119 & 353 & 22 & 77 \\
\hline Solucan G. & 2.8 & 0.37 & 0.34 & 7.98 & 0.39 & 1791 & 71 & 166 & 10 & 17 \\
\hline Tavuk G. & 3 & 1.76 & 2.16 & 10.16 & 0.78 & 3690 & 290 & 432 & 43 & 54 \\
\hline $\begin{array}{c}\text { Mineral G. } \\
\text { Üre }\end{array}$ & 46 & - & - & - & - & - & - & - & - & - \\
\hline
\end{tabular}

parseller deneme desenine göre üç tekerrürlü olarak kurulmuștur. Deneme 3 farklı organik gübre (Sığır gübresi, Solucan gübresi, Tavuk gübresi), 1 adet mineral gübre (Üre) ve kontrol uygulaması olmak üzere toplam 5 uygulamadan olușmaktadır. Gübrelerin uygulanma dozlarında, karabuğday bitkisinin intiyaç duyduğu N miktarı esas alınarak kullanılan gübrelerin toplam N içerikleri $4 \mathrm{~kg} \cdot \mathrm{da}^{-1} \mathrm{~N}$ olacak șekilde hesaplanmıș ve parsellere uygulanmıștır.

Organik gübrelerin kimyasal analiz sonuçları Çizelge 1'de verilmiștir. Hesaplanan gübre oranları deneme toprağına ekimle birlikte ilave edilmiștir.

Karabuğday çeșitleri 15 Nisan 2019 tarihinde sıra arası $25 \mathrm{~cm}$ sıra üzeri $5 \mathrm{~cm}$ olacak șekilde parsellere ekimi yapılmıștır. Parsel boyu $3 \mathrm{~m}$ parsel genișliği $1.5 \mathrm{~m}$ olup parsel boyutu $4.5 \mathrm{~m}^{2}$ dir. Hasat 10 Temmuz 2019 tarihinde gerçekleștirilmiș, birim $\mathrm{m}^{2}$ alanda bitki kökleri örneklenip yıkandıktan sonra laboratuvarda WinRhizo programı yardımı ile bitki kök morfolojik özellikleri belirlenmiștir.

Araștırma sonucunda elde edilen veriler JMP 8 istatistik paket programı kullanılarak ANOVA analizi yapılmıș olup LSD testine tabi tutulmuștur.

\section{BULGULAR VE TARTIȘMA}

Organik ve inorganik gübre uygulamalarının karabuğday bitkisinin toplam kök uzunluğu ve kök yüzey alanı üzerine etkisine ait ortalama değerler Çizelge 2'de verilmiștir.

Organik ve inorganik gübre uygulamalarının karabuğday bitkisinin toplam kök uzunluğu üzerine etkileri incelendiğinde çeșitler arasında istatistiksel olarak önemli farkllıklar çıkmazken hem gübre uygulamaları arasında hem de gübre $x$ çeșit interaksiyonları arasında istatistiksel olarak önemli ( $p<0.001)$ bulunmuștur (Çizelge 2). Gübreçeșit interaksiyonları arasında en yüksek toplam kök uzunluğu Güneș çeșidinde tavuk gübresi uygulamasından $\left(44.82 \mathrm{~km} \mathrm{da}^{-1}\right)$ elde edilmiștir. Gübre uygulamaları içerisinde değerlendirildiğinde yine en yüksek toplam kök uzunluğunun tavuk gübresinden $\left(39.68 \mathrm{~km} \quad \mathrm{da}^{-1}\right)$ elde edildiği görülmektedir. Yang vd. (2004) yaptıkları çalıșmada organik gübre uygulamalarının kimyasal gübre uygulamasına göre bitki kök uzunluğunu arttırdığı görülmektedir. Ayrıca Ji vd. (2017) yaptıkları çalıșma da araștırmamızı destekler niteliktedir.

Organik ve inorganik gübre uygulamalarının karabuğday bitkisinin kök yüzey alanı üzerine

Çizelge 2. Organik ve İnorganik gübre uygulamalarının karabuğday bitkisi toplam kök uzunluğu ve kök yüzey alanına etkisi Table 2. The effect of organic and inorganic fertilizer applications on total root length and root surface area of buckwheat plant

\begin{tabular}{|c|c|c|c|c|c|c|}
\hline \multirow[t]{2}{*}{ Uygulama } & \multicolumn{3}{|c|}{ Toplam uzunluk km da' } & \multicolumn{3}{|c|}{ Kök Yüzey Alanı m² da-1 } \\
\hline & Aktaș & Güneș & Ortalama & Aktaș & Güneș & Ortalama \\
\hline Tavuk & $34.54 \mathrm{~B}$ & $44.82 \mathrm{~A}$ & 39.68 a & $377.27 \mathrm{~B}$ & $339.92 \mathrm{C}$ & 358.59 а \\
\hline Solucan & $25.22 \mathrm{C}$ & $19.81 \mathrm{D}$ & $22.52 \mathrm{c}$ & $326.01 \mathrm{D}$ & $231.86 \mathrm{G}$ & $278.93 \mathrm{c}$ \\
\hline Sığır & $25.67 \mathrm{C}$ & $20.29 \mathrm{D}$ & $22.98 \mathrm{c}$ & $262.68 \mathrm{~F}$ & $197.82 \mathrm{H}$ & $230.25 d$ \\
\hline Üre & $32.68 \mathrm{~B}$ & $22.87 \mathrm{CD}$ & 27.78 b & $395.10 \mathrm{~A}$ & $274.13 \mathrm{E}$ & $334.62 \mathrm{~b}$ \\
\hline Kontrol & $14.24 \mathrm{E}$ & $8.23 \mathrm{~F}$ & $11.23 \mathrm{~d}$ & 166.271 & $123.65 \mathrm{~J}$ & $144.96 \mathrm{e}$ \\
\hline Ortalama & $26.47 a$ & 23.20 a & & 305.47 a & $233.47 \mathrm{~b}$ & \\
\hline$E G F^{\prime}=\ddot{O D}$ & $E G F^{2}=1.31 * *$ & $\mathrm{EGF}^{3}=2.32 * *$ & & $E G^{\prime}=0.73 * *$ & $\mathrm{EGF}^{2}=2.44^{* *}$ & $\mathrm{EGF}^{3}=4.89 * *$ \\
\hline
\end{tabular}


etkileri incelendiğinde hem çeșitler arasında, hem gübre uygulamaları arasında hem de gübre $x$ çeșit interaksiyonları arasında istatistiksel olarak önemli ( $p<0.001$ ) bulunmuștur (Çizelge 2). Çeșitler arasında Aktaș çeșidinin Güneș çeșidine kıyasla kök yüzey alanının daha iyi olduğu, gübre uygulamaları arasında tavuk gübresinin diğer uygulamalardan daha iyi olduğu ve çeșit x gübre interaksiyonları arasında ise Aktaș çeșidinde üre uygulamasının daha iyi olduğu sonucuna varılımıștır. Organik gübre uygulamasının bitki kök yüzey alanını arttırdığına dair literatürde çalıșmalar mevcuttur. Örneğin; Ji vd. (2017) yaptıkları çalıșmada organik kaynaklı gübre uygulamalarının kök yüzey alanını arttırdığı görülmektedir. Ayrıca çeșitler arasında Aktașin daha iyi çeșit olmasının nedeni genotipsel farklıık olabilir. Eissenstat (1997) yaptığı çalıșmada bitki türü ve çeșidine bağlı olarak kök yapısının (morfolojisi) değișim gösterebildiğini belirtmiștir.

Organik ve inorganik gübre uygulamalarının karabuğday bitkisinin kök hacmi ve kök çapı üzerine etkisine ait ortalama değerler Çizelge 3'de verilmiștir.

Organik ve inorganik gübre uygulamalarının karabuğday bitkisinin kök hacmi üzerine etkileri incelendiğinde çeșitler, gübre uygulamaları ve gübre $x$ çeșit interaksiyonları arasında istatistiksel olarak önemli ( $p<0.001)$ bulunmuștur (Çizelge 3 ). Çizelge 3 incelendiğinde her iki çeșitte de üre ve tavuk gübresi uygulamaları en iyi uygulamalardır. Örneğin; Baldi vd. (2010) yaptıkları çalıșmada araștırma bulguları organik gübre ve kimyasal gübre uygulamalarının kök gelișimini arttırdığını göstermektedir. Ayrıca, organik gübre uygulamalarının kök hacmini arttırdığına dair literatürde pek çok çalıșma vardır (Eissenstat, 1997; Ji vd., 2017).
Organik ve inorganik gübre uygulamalarının karabuğday bitkisinin kök çapı üzerine etkisi incelendiğinde çeșitler arasında istatistiksel olarak önemli farklılıklar çıkmazken hem gübre uygulamaları arasında hem de gübre $x$ çeșit interaksiyonları arasında istatistiksel olarak önemli $(p<0.001)$ bulunmuștur (Çizelge 3). Farklı çeșit ve uygulamalar altında bitki kökleri farklı çaplarda gelișebilmektedir (Hodge vd., 2009).

\section{SONUC̣LAR}

Bir bitkinin sağlıklı ve verimli olması için kök sisteminin gelișmiș olması gerekir. Araștırma bulgularımızda Aktaș karabuğday çeșidi kök morfolojik özellikleri Güneș karabuğday çeșidinden daha yüksek olduğu belirlenmiștir. Araștırma bulgularımız kök gelișim parametreleri olarak (kök uzunluğu, kök yüzey alanı, kök hacmi ve kök çapı) en iyi sonuçların üre ve tavuk gübresi uygulanan parsellerde elde edildiği belirlenmiștir. Üre ve tavuk gübrelerinin azot içeriği diğer organik gübrelerden daha yüksek içeriktedir. Ayrıca tavuk gübresi de yüksek P içeriğine sahiptir. Dolayısıyla etkili bir kök sistemi için mineral gübre uygulamasına alternatif olarak organik gübre kaynağı olan tavuk gübresi kullanılabilir.

\section{KAYNAKLAR}

Acar R, Güneș A, Topal I, Gummadov N, (2011). Farklı bitki sıklıklarının karabuğday'da (Fagopyrum esculentum Moench.) verim ve bazı verim unsurlarına etkisi. Selcuk Journal of Agriculture and Food Sciences 25: 47-51.

Alagöz Z, Yilmaz E, Öktüren F, (2006). Organik Materyal İlavesinin Bazi Fiziksel ve Kimyasal Toprak Özellikleri Üzerine Etkileri. Akdeniz Üniversitesi Ziraat Fakültesi Dergisi, 19(2), 245-254.

Anonim, (2019). http://www.hurriyet.com.tr/haberleri/ gubre-fiyatlari. Erișim tarihi:26.11.2019

Çizelge 3. Organik ve inorganik gübre uygulamalarının karabuğday bitkisi kök hacmi ve kök çapına etkisi

Table 3. The effect of organic and inorganic fertilizer applications on root volume and root diameter of buckwheat plant
Uygulama
Kök hacmi (m3 da $\left.^{-1}\right)$
Kök çapı (mm)

\begin{tabular}{|c|c|c|c|c|c|c|}
\hline & Aktaș & Güneș & Ortalama & Aktaș & Güneș & Ortalama \\
\hline Tavuk & $0.0301 \mathrm{~A}$ & 0.0187 CD & $0.0245 a b$ & $0.301 \mathrm{~F}$ & $0.310 \mathrm{EF}$ & $0.305 d$ \\
\hline Solucan & $0.0250 \mathrm{~B}$ & $0.0217 \mathrm{BC}$ & $0.0234 \mathrm{bc}$ & $0.305 \mathrm{~F}$ & $0.420 \mathrm{AB}$ & $0.363 \mathrm{bc}$ \\
\hline Sığır & $0.0240 \mathrm{~B}$ & $0.0161 \mathrm{D}$ & $0.0200 \mathrm{c}$ & $0.430 \mathrm{~A}$ & $0.377 \mathrm{ABCD}$ & 0.403 a \\
\hline Üre & $0.0326 \mathrm{~A}$ & 0.0220 BC & 0.0273 a & $0.325 \mathrm{DEF}$ & $0.364 \mathrm{BCDE}$ & $0.345 c$ \\
\hline Kontrol & $0.0165 \mathrm{D}$ & $0.0148 \mathrm{D}$ & $0.0157 d$ & $0.361 \mathrm{CDE}$ & $0.409 \mathrm{ABC}$ & $0.385 a b$ \\
\hline Ortalama & 0.0256 a & $0.0186 \mathrm{~b}$ & & $0.345 a$ & 0.376 a & \\
\hline$E G F^{\prime}=0.0010$ & $\mathrm{EGF}^{2}=0.0015^{* *}$ & $E G F^{3}=0.0030 * *$ & & $E G^{\prime}=O ̈ D$ & $\mathrm{EGF}^{2}=0.022 * *$ & $E G F^{3}=0.044^{* *}$ \\
\hline
\end{tabular}


Baldi E, Toselli M, Eissenstat D, Marangoni B, (2010). Organic fertilization leads to increased peach root production and lifespan. Tree Physiology 30: 1373-1382.

Chauhan RS, Gupta N, Sharma SK, Rana JC, Sharma TR, Jana S, (2010). Genetic and genome resources in buckwheatpresent status and future perspectives. Buckwheat 2: 33-44.

Chen JH, (2006). The combined use of chemical and organic fertilizers and/or biofertilizer for crop growth and soil fertility. In International workshop on sustained management of the soil-rhizosphere system for efficient crop production and fertilizer use (Vol. 16, p. 20). Land Development Department Bangkok Thailand.

Eissenstat, D.M. 1997. Trade-offs in root form and function. Ecology in agriculture: 173-199.

Hayit F, Hülya G, (2015). Karabuğday'ın Sağlık Açısından Önemi ve Unlu Mamüllerde Kullanımı. Uludağ Üniversitesi Ziraat Fakültesi Dergisi 29: 123-132.

Hodge A, Berta G, Doussan C, Merchan F, Crespi M, (2009). Plant root growth, architecture and function. Plant and soil 321: 153-187.

Ji R, Dong G, Shi W, Min J, (2017). Effects of liquid organic fertilizers on plant growth and rhizosphere soil characteristics of chrysanthemum. Sustainability 9: 841.

Soyergin S, (2003). Organik Tarimda Toprak Verimliliğinin Korunmasi, Gübreler ve Organik Toprak Iyileștiricileri.

Su R, Zhou R, Mmadi MA, Li D, Oin L, Liu A, ...., Wu Z, (2019). Root diversity in sesame (Sesamum indicum L.): insights into the morphological, anatomical and gene expression profiles. Planta 250: 1461-1474.

Svačina P, Středa T, Chloupek O, (2014). Uncommon selection by root system size increases barley yield. Agronomy for sustainable development 34: 545-551.

Wang Z, Ma BL, Gao J, Sun J, (2015). Effects of different management systems on root distribution of maize. Canadian Journal of Plant Science 95: 21-28.

Yang C, Yang L, Yang Y, Ouyang Z, (2004). Rice root growth and nutrient uptake as influenced by organic manure in continuously and alternately flooded paddy soils. Agricultural Water Management 70: 67-81. doi:https://doi. org/10.1016/j.agwat.2004.05.003. 